\title{
Taiwan's Offshore Wind Energy Policy: From Policy Dilemma to Sustainable Development
}

\author{
Huey-Shian Chung
}

check for updates

Citation: Chung, H.-S. Taiwan's Offshore Wind Energy Policy: From Policy Dilemma to Sustainable Development. Sustainability 2021, 13, 10465. https://doi.org/10.3390/ su131810465

Academic Editor: M.

Sergio Campobasso

Received: 8 August 2021

Accepted: 18 September 2021

Published: 20 September 2021

Publisher's Note: MDPI stays neutral with regard to jurisdictional claims in published maps and institutional affiliations.

Copyright: (C) 2021 by the author. Licensee MDPI, Basel, Switzerland. This article is an open access article distributed under the terms and conditions of the Creative Commons Attribution (CC BY) license (https:// creativecommons.org/licenses/by/ $4.0 /)$.
Bachelor Degree Program in Ocean Law and Policy, National Taiwan Ocean University, Keelung City 202, Taiwan; hschung@mail.ntou.edu.tw

\begin{abstract}
Taiwan's offshore wind energy policy (OWE policy) is a response to sustainable development goals. Offshore wind energy has become one of the fastest growing renewable energies on Taiwan's coastline, with the government's full support for the promotion and implementation of the OWE policy. With the operation of Taiwan's first wind farm in 2021, increasing controversies are specifically concerned with the distribution of social, economic, and environmental burdens and benefits resulting from the OWE policy. More offshore wind farms are forthcoming by 2025 . However, little attention has been paid to policy dilemmas for many aspects relevant to sustainable development. Therefore, this paper conducts a policy analysis to construct policy-relevant information of the OWE policy and identifies policy dilemmas in relation to concerns about sustainable development. This paper presents policy recommendations on the design and decision-making processes for facilitating the smooth promotion and implementation of Taiwan's OWE policy and future renewable energy policies.
\end{abstract}

Keywords: offshore wind energy; sustainable development; Taiwan

\section{Introduction}

The development of major economic sectors, from the primary extraction of raw materials, to the tertiary distribution of goods and services, is highly reliant on energy. However, conventional energy sources, such as fossil fuels and coal are finite, and their combustion has been considered as a major cause of air pollution and global warming. In response, sustainable development goal seven, (SDG 7) one goal among 17 different time-bound but interrelated topic areas in the "UN Sustainable Development Goals" (SDGs) announced in 2015, is about sustainable energy [1]. It sets up clear objectives for the next energy transition for global society. The goals of energy services in the future should be affordability, reliability, and renewability [2]. Increasing the generation of renewable energy to sustain energy supply has rapidly become a priority worldwide, and offshore wind energy has become a viable option for some countries, such as the UK [3,4], Sweden [5], Netherlands, Denmark, Germany [6], and China [7], among others.

In the last decade, Taiwan's government has invested substantial political and financial resources into developing new energy sources, particularly offshore wind energy. The plan to utilize offshore wind energy in Taiwan is unprecedented. Therefore, during the course of promoting offshore wind energy, Taiwan has encountered considerable technical and institutional challenges, as well as opposition from marine stakeholders. The literature on Taiwan's offshore wind energy has primarily focused on achieving scientific and technological breakthroughs in offshore wind energy [8,9]. Few studies have contributed to improving administrative and regulatory measures to support the development of offshore wind energy [10-13]. For example, Huang et al. [10] applied a technological system to study the status of wind power in Taiwan from 2000 to 2007 and provided strategies to increase the market penetration of wind power technologies. Additionally, Liou [11] analyzed economy mechanisms of wind policy between 2000 and 2005, including tax incentives, 
tariffs, export credit subsidies, purchasing rates, and so on in order to estimate the potential of Taiwan's wind energy industry for entering the international market. These two references provide thoughtful insights into the economic outlook of Taiwan's OWE policy in the early stage, but there was little discussion about offshore wind development after 2010. Kao et al. [12] offered an updated proposal for Taiwan's offshore wind energy, one that emulated Japan's administrative model to improve Taiwan's regulatory measures of offshore wind energy development. Specifically, their study recommended consideration of offshore wind issues within the scheme of an ocean policy framework rather than energy policy. Furthermore, Zhang et al. [13] examined the conflicts between fishing and offshore wind activities in the overlapping marine zones in Changhua, Taiwan, suggesting the application of marine spatial planning to address these issues. These two studies justified the need to consider the ocean characteristics of Taiwan's OWE policy while developing and improving the offshore wind sector. Unfortunately, in view of the above, very little attention has been placed on the effects of regulations after 2010, specifically the interaction of the three elements of sustainable energy development in the OWE policy, as shown in Table 1.

Table 1. A comparison of the referenced literature in relation to research time frame and elements of sustainable development.

\begin{tabular}{cccccc}
\hline & \multicolumn{2}{c}{ Time Frame } & \multicolumn{2}{c}{ Elements of Sustainable Development } \\
\cline { 2 - 6 } & Before 2010 & After 2010 & Economy & Society & Environment \\
\hline Huang et al. [10] & $\mathrm{V}$ & $\mathrm{X}$ & $\mathrm{V}$ & $\mathrm{X}$ & $\mathrm{X}$ \\
Liou [11] & $\mathrm{V}$ & $\mathrm{X}$ & $\mathrm{V}$ & $\mathrm{X}$ & $\mathrm{X}$ \\
Kao et al. [12] & $\mathrm{X}$ & $\mathrm{V}$ & $\mathrm{X}$ & $\mathrm{X}$ & $\mathrm{X}$ \\
Zhang et al. [13] & $\mathrm{X}$ & $\mathrm{V}$ & $\mathrm{V}$ & $\mathrm{V}$ & $\mathrm{X}$ \\
\hline
\end{tabular}

V: research focus; $X$ : not research focus.

Another possible reason that Taiwan's government fully supports offshore wind energy might be linked to general public opinion. Opinions on conventional energy and renewable energy in Taiwan's society have been divergent [14,15]. Education in Taiwan taught students that fossil fuels, which generate carbon emissions, are bad. By contrast, renewable energy, such as offshore wind energy, is linked to modernity, cleanliness, innovation, and progress $[14,15]$. The operation of Taiwan's first offshore wind farm since the first quarter of 2021 has publicly heightened discussions and scrutiny on this issue. According to one of Taiwan's biggest Latent Semantic Analysis databases, a search of the keywords "conventional energy" and "renewable energy" (in Chinese), resulted in 31,930 online messages. Predictably, $41 \%$ were in favor of renewable energy, while only $7 \%$ displayed positive attitudes toward conventional energy, as shown in Table 2 [16]. Such diametric attitudes show the existence of tensions between renewable energy and conventional energy sectors. Nevertheless, the disadvantages generated from conventional energy might be exaggerated and the shortcomings resulting from renewable energy might be overlooked. Concerns about an unbalanced equilibrium resulting from the OWE policy, where economic development is pursued at the expense of social equity and environmental protection, have been continuously raised $[17,18]$. However, little attention has been paid to the policy dilemmas or challenges resulting from the OWE policy.

Table 2. A public attitude survey on energy issues during the period from 1 January to 31 March 2021. Source: [16]; this paper arranged the table.

\begin{tabular}{ccccc}
\hline & \multicolumn{2}{c}{ Conventional Energy } & \multicolumn{2}{c}{ Renewable Energy } \\
\cline { 2 - 5 } & Pieces of Messages & Percentage & Pieces of Messages & Percentage \\
\hline Positive attitude & 2178 & $7 \%$ & 13,061 & $41 \%$ \\
Negative attitude & 7986 & $25 \%$ & 8725 & $27 \%$ \\
\hline
\end{tabular}


Public policies are seldom perfect. Identifying and addressing policy dilemmas or challenges can improve implementation of current policies and the design of future policies. Therefore, this paper argues that the practice of the OWE policy should be consistent with a sustainable development ethic to reconcile public concerns with the developmental needs of society. To achieve this, it firstly reviews the OWE policy to establish policy relevant knowledge. Secondly, this paper identifies dilemmas of the OWE policy from the perspective of sustainable development and policy suggestions. The final section of this paper provides policy implications. The OWE policy is an important step for Taiwan in achieving a sustainable future, so a critical review of the policy will advance its goals.

\section{Materials and Methods}

This paper is a qualitative policy analysis conducted using a policy analysis perspective and a sustainable development perspective, as shown in Figure 1. A qualitative policy analysis is beneficial for its ability to make seemingly unmanageable public policy become manageable [19]. It can be viewed as a process and also a product [20]. As a process, this paper applies a policy analysis perspective and a sustainable development perspective to examine materials from a wide range of government documents, think-tank statistics, and academic literature to study the OWE policy and identify policy dilemmas. As a product or an outcome, this paper presents policy suggestions to improve unanticipated performances resulting from the OWE policy.

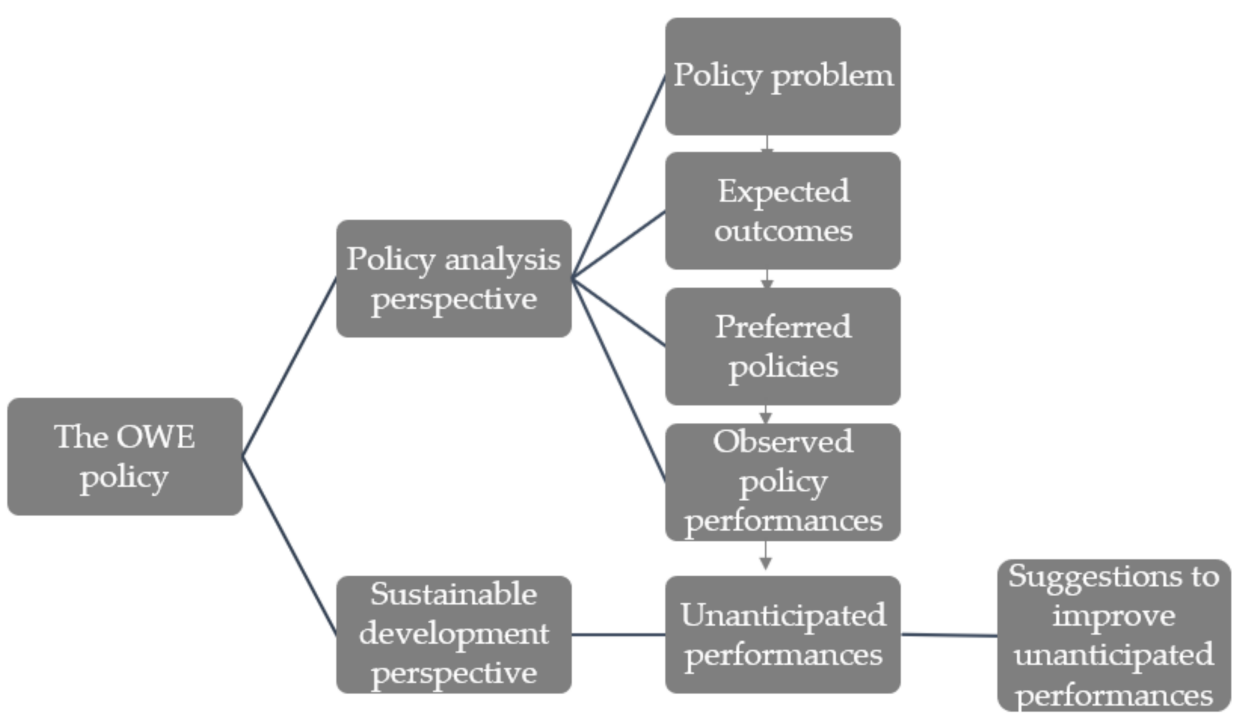

Figure 1. The research process on Taiwan's OWE policy.

\subsection{Policy Analysis Perspective}

The OWE policy is part of the package of Taiwan's energy transition plan to achieve sustainable development, so the OWE policy is constructed by a series of renewable energy policies and laws. In order to understand the OWE policy, this paper provides systematic policy-relevant knowledge of the OWE policy using Dunn's policy analysis [21] for structuring policy problems, expected outcomes, preferred policies, and policy performances of the OWE policy in Section 3 of this paper. Policy problems refer to public problems. Expected policy outcomes are the government's visions or ambitions for adopting one or more policy alternatives designed to solve policy problems. Preferred policies are potential solutions to the policy problems. Policy performances concern how much a policy outcome has contributed to solving policy problems and if there are unanticipated outcomes [21].

\subsection{Sustainable Development Perspective}

The sustainable development discourse dates back to the publication of the "Report of the World Commission on Environment and Development: Our Common Future" 
in 1987. It defined sustainable development as development that "meets the needs of the present without compromising the ability of future generations to meet their own needs [22]." Over the last 30 years, the concept of sustainable development continued to be enriched in international laws and instruments such as the 1992 Rio Declaration on Environment and Development [23], the 2000 Millennium Declaration [24], the 2002 Johannesburg Declaration on Sustainable Development [25], and the 2015 SDGs [1]. The idea of sustainable development has been shifted from a political claim, to policies and laws and has become a common goal for the current generation.

The concept of sustainable development has many contradicting facets by nature, which often cause dilemmas for policy makers while they are planning and implementing policies. The concept of sustainable development involves three components: environment, economy, and equality (the three Es). The three Es refer to maintaining environmental sustainability in order to support quality of life, maintain income and economic growth, and maintain human rights and equality to ensure social sustainability, respectively [26]. Implementing sustainable development policies necessitates striking a balance between the three Es. This is challenging. When one is promoted, the other two will fall into disequilibrium. Moreover, organizing the three Es into random pairwise combinations causes clashes between their goals and directions [27]. Campbell [28] referred to this as "the planner's triangle," i.e., the balance between social equity and economic development tends to spur conflict over property accumulation and distribution; the balance between economic development and environmental protection tends to incur conflicts over resource use; while the balance between environmental protection and social equity tends to incite disputes over development and developmental models. The planner's triangle approach is a heuristic and aspirational approach for analyzing public policy against the idea of sustainable development [29]. Section 4 of this paper applies the planner's triangle to identify Taiwan's OWE policy dilemmas and presents recommendations to address policy dilemmas.

\section{Taiwan's Offshore Wind Energy Policy-Relevant Knowledge \\ 3.1. Policy Problems}

After transforming into a democratic and capitalist society in the 1980s, the subsequent decade saw Taiwan experience a period of rapid fossil-fuel-based economic growth and prosperity. Maintaining sustainable development in all aspects of life benefits all levels of Taiwan's society. However, in recent decades, due to internal and external factors, concerns on the energy structure have been raised.

An increasing discussion about the correlation between climate change and energy has been taking place at the global level since the 1980s. The Intergovernmental Panel on Climate Change (IPCC) has begun to place great emphasis on the correlation between energy use and climate change. The IPCC suggested that if humanity intends to continue its development of this planet, the generation of greenhouse gases must be reduced in order to mitigate global warming [30]. The first multilateral convention addressing climate change, the United Nations Framework Convention on Climate Change, was adopted in 1992 [31] and a series of international campaigns and negotiations on carbon dioxide emissions from fossil fuel combustion has begun.

As of 2020, Taiwan's top five energy sources are coal (43.3\%), natural gas (21.4\%), nuclear energy (12.7\%), petroleum (5.8\%), and renewable energy (3.5\%) [32]. Taiwan is a densely populated island. Climate change and air pollution have caused multidimensional adverse impacts on society in Taiwan $[33,34]$. If the energy consumption structure remains the same, most of the livable areas in Taiwan may be inundated. Taiwan's major agricultural production zones and cities are located in low-lying or coastal areas. Research showed that, by 2050, the projected sea level of Taiwan's coast would reach $200 \mathrm{~m}$ and $90 \mathrm{~m}$ relative to the estimated sea level in 2012, respectively [35]. In addition, air pollution may lead to more diseases in Taiwan, such as cardiovascular disease [36]. Therefore, local protests and 
social movements in Taiwan against the effects of greenhouse gas emissions have never disappeared $[37,38]$.

Furthermore, approximately $98 \%$ of Taiwan's energy is imported. The high dependence on imported energy challenges energy security. The concept of energy security encompasses aspects such as stable supply, affordable prices, and freedom of choice [39]. The stable supply of energy, at affordable prices, ensures socio-economic prosperity both domestically and globally. Some of the major industries in Taiwan, such as the global frontier, a semiconductor industry, are energy-intensive [40]. However, the world energy market contains political factors. International conflicts are often waged over the monopolization of petroleum and gas pipelines, and international politics manages the price and supply of conventional energy [39]. Therefore, although the import of energy sources has contributed to Taiwan's socio-economic growth, which may further allow people to have ability and freedom to choose high-quality lifestyles, a high level of imported energy dependence places Taiwan in a vulnerable situation.

The above facts have become arguments for making a political decision on the transformation of the current imported fossil fuel-dependent energy system. Looking for new and self-generated energy has been part of the pathway to achieving a sustainable future in Taiwan.

\subsection{Expected Policy Outcomes}

The development of offshore wind energy is parallel to the progress of energy transition. Therefore, the expected policy outcomes of the OWE policy are rooted in a vision of energy transition. The direction of energy transition in Taiwan is composed of two high-level documents, the 2008 "Framework of Taiwan's Sustainable Energy Policy" (the Framework Policy) [41] and the 2009 Renewable Energy Development Act [42], and one international commitment, the 2015 UN SDGs [1].

The Executive Yuan, which is the highest level of administrative authority in Taiwan, adopted the Framework Policy in 2008 as the principle policy document to guide the direction of future energy transition work. The purpose of the Framework Policy is energy security, economic development, and environmental protection. In order to meet the development needs of future generations, increasing energy efficiency, developing clean energy, and securing a stable energy supply are the policy goals [41].

After the adoption of the Framework Policy, the Executive Yuan requested relevant competent authorities to draft promotion and implementation strategies. The Ministry of Economic Affairs (MOEA) under the Executive Yuan, is the competent authority on economy, energy and industry matters. A subordinate body of the MOEA, the Bureau of Energy (BOE) is in charge of energy policy and affairs. Since then, the MOEA and the BOE are two major authorities administrating energy transition work. Therefore, in the offshore wind energy affairs, MOEA takes a leading role in undertaking cross-sectoral work to support the OWE policy. The BOE administrates wind farm zoning and implementing the policy.

If the Framework Policy articulated expected outcomes, the Renewable Energy Development Act defined renewable energy and created a mandatory duty for public and private sectors to develop and utilize renewable energy to achieve the expected outcomes. The MOEA promulgated the Renewable Energy Development Act in 2009. This Act firstly recognizes wind energy and solar energy with other energy that is approved for sustainable use by the competent authority as renewable energy [42]. The Renewable Energy Development Act also required that new construction, expansion, and reconstruction of public constructions or public buildings should involve the installation of renewable energy power-generation facilities if the condition is available. Private companies, whose electricity use exceeds a certain capacity, should "install renewable energy power generation and storage facilities with a certain installed capacity, or purchase a certain amount of electricity generated from renewable energy and a certificate" [42]. This Act created a demand for renewable energy to boost energy transition. 
Moreover, Taiwan's expected policy outcomes of energy transition have been influenced by international society. Particularly, the 68th UN General Assembly announcement of the "UN SDGs" in 2015 which comprised of 17 goals and 169 targets (United Nations, 2015c). Specifically, SDG 7 directly addresses the topic of energy, which seeks to ensure that all of humanity can enjoy access to affordable, stable, sustainable, and modern energy. Furthermore, it places particular emphasis on the development of clean, low-carbon, or even zero-carbon energy [2]. SDG 7 integrates the elements of social equity, environmental protection, and economy development into energy policies. In response to the SDGs, Taiwan's National Council for Sustainable Development, which serves as a platform for all ministries and agencies of Taiwan's government to promote sustainable development, referred to the UN SDGs and passed the "Taiwan Sustainable Development Goals" (Taiwan SDGs) in 2019. Target 7 of the Taiwan SDGs linked energy transition to a low-carbon economy and society into the concept of sustainable development. It called for increasing the amount of electricity generated from renewable energy to $20 \%$, establishing a renewable energy capacity of $3100 \mathrm{KW}$, and ensuring modern energy for all by 2030 [43].

Overall, developing clean and renewable energy including offshore wind energy to promote energy transition is expected to be useful to combat climate change and increase energy security. Deepening the expected outcomes to sustain Taiwan's future is all the government want.

\subsection{Preferred Policies}

In order to make Taiwan a sustainable society through energy transition, developing an independent supply of renewable and clean energy is imperative. Possible options for such energy sources in Taiwan include nuclear power, solar energy, and land-based and offshore wind energy.

Nuclear power is one of the earliest developed renewable energies. However, after the nuclear accident at the Fukushima Daiichi Nuclear Power Plant in Japan in 2011, Taiwan's society started a heated debate on the safety issues of its own nuclear power plants [44]. Public opinions on the safety of nuclear energy showed distrust and opposition [45]. Taiwan's government announced the "Nuclear-free Homeland Action Plan" in 2016, aimed at becoming nuclear energy free by 2025 [46]. In March 2021, the government further emphasized Taiwan's energy transition in the following direction: increasing the usage of renewable energy, green energy and natural gas, reducing the generation of coal-fired electricity, and becoming nuclear energy free [47]. Therefore, nuclear energy has not been a favorable option for Taiwan's energy transition. The decommission of nuclear power plants has been scheduled by Taiwan's government [48], as shown in Table 3.

Table 3. The decommission schedule of nuclear power plants.

\begin{tabular}{ccc}
\hline Nuclear Power Plants & Nuclear Facilities & Decommission Schedule \\
\hline \multirow{2}{*}{ The first nuclear power plant } & Facility 1 & December 2018 \\
& Facility 2 & July 2019 \\
The second nuclear power plant & Facility 1 & December 2021 \\
& Facility 2 & March 2023 \\
The third nuclear power plant & Facility 1 & July 2024 \\
& Facility 2 & May 2025 \\
\hline
\end{tabular}

Solar energy and land-based wind energy were the prevalent options to develop renewable energy in Taiwan. By March 2021, land-based wind energy provided 93.7 MV, and solar energy was 576.8 MV [49]. However, both solar energy and land-based wind energy installations require land. Taiwan is an island of approximately $36,000 \mathrm{~km}^{2}$. The population density in 2021 is 650 persons $/ \mathrm{km}^{2}$. With such scarcity of land and high density of population, designating space for more large-scale solar farms or land-based wind farms is challenging [12]. In addition, the noise resulting from the operations of land-based wind turbines has caused neighborhood opposition toward further installations of wind 
turbines [50]. Therefore, increasing the capacities of solar energy and on-land wind energy is becoming gradually more difficult.

Taiwan is surrounded by seas. Wind energy is abundant and is completely renewed each day. Some research has provided scientific data about offshore wind energy. Chen et al. [51] observed that the highest wind speed was estimated to be up to $7 \mathrm{~m} / \mathrm{s}$ on the West Bank of Taiwan. Chuang et al. [52] estimated that the average generation of monthly offshore wind power was approximately 550 GWh from May to August and could be higher between October to March at above 1000 GWh. Gradually, offshore wind has become the optimal choice among renewable energy options in Taiwan [53]. In 2017, the Executive Yuan announced the "Forward-looking Infrastructure Development Program" (FIDP) to renovate a new generation of infrastructure for national development in the next 30 years, including offshore wind energy infrastructure [54]. To implement the FIDP, shortly afterwards the "Four-Year Wind Power Promotion Plan (The Promotion Plan)" was initiated by the MOEA in the same year. The Promotion Plan launched Taiwan's OWE policy under a vision of energy security, green economy, and environmental sustainability. It defines the following targets of: providing a total of $20 \%$ renewable energy energy sources and generating $3000 \mathrm{MW}$ of offshore wind power annually by 2025 [55]. The OWE policy, which served as one pillar of energy transition work, has a timeframe.

The OWE policy rollout is divided into three phases as detailed in Figure 2. The first phase, "demonstration incentive program", viewed as a pilot incentive program, involves demonstration awards. Specifically, the BOE selected wind turbine manufacturers and operating companies, and subsidized construction of wind turbines and wind farms. The two demonstration units were scheduled to complete in 2020. The second phase, "zone application planning", involves announcements and applications of potential sites. The BOE selected 36 potential sites, of which 24 remained after excluding the navigation channels of transportation vessels, for manufacturers and operating companies to choose from and apply for development. To acquire the exclusive development privilege, the vendors were required to complete the necessary environmental assessments by 2017. The construction of the wind turbines is expected to be completed by 2025 [56]. In the BOE's "Draft of Application for Development and Site Planning of Offshore Wind Power Zones," the third phase, "zonal development", will open in the middle of 2021, with vendors evaluating the sites themselves and applying to develop the sites in accordance with relevant laws and regulations [57].
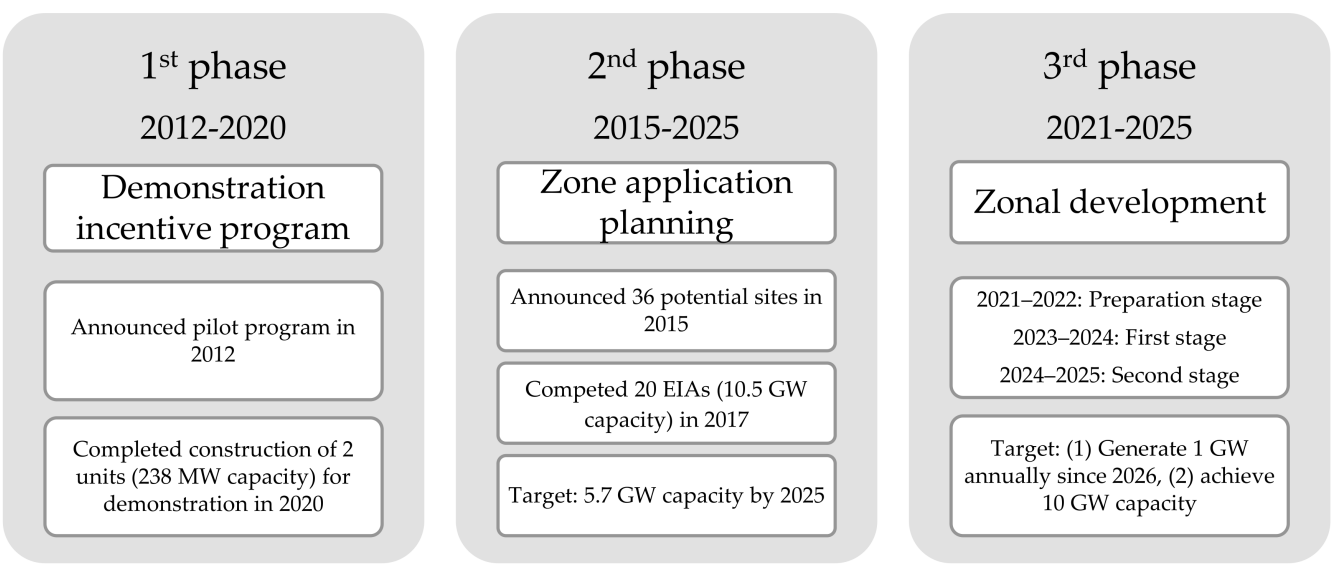

Figure 2. The three phases of Taiwan's OWE policy.

\subsection{Policy Performances}

Under the first phase of the OWE policy, as shown in Figure 2, two units (238 MW capacity) for demonstration were scheduled to begin operation in 2020. However, only one offshore wind farm at business scale, the $128 \mathrm{MW}$ Formosa I, has started operating as of February 2021 [58,59]. The developments of other potential wind farms including 
Yunlin [60,61] and Changhua offshore wind farms [62] have either been suspended due to controversies on their environmental assessments or tied down by red tape due to stakeholders' opposition. The contribution of the offshore wind energy to addressing climate change and energy safety at this stage is ambiguous. The end of the third phase of Taiwan's OWE policy in 2025 could be a suitable period to further examine the performance of the OWE policy on improving energy security and reducing greenhouse gases. The unanticipated outcomes of the OWE policy, which have caused a delay in the policy schedule, are examined in Section 4 of this paper.

\section{Policy Dilemmas of Taiwan's Offshore Wind Energy Policy and Suggestions}

The OWE policy was designed with good intentions to support Taiwan's energy transition and to respond to SDG 7. However, it has encountered unanticipated outcomes mostly resulting from the conflict between the three Es: economic development, environmental protection, and social equity. For economic development, the establishment of offshore wind farms is expected to increase power generation and stimulate the growth of the green energy industry. Offshore wind farms may also serve as demonstration sites for other countries to study, thereby enhancing the international competitiveness of Taiwan's green energy industry. For environmental protection, offshore wind power is expected to protect the environment, conserve resources and alleviate the greenhouse gas effect by reducing carbon dioxide emissions from fossil fuel combustion. With regard to social equity, the implementation and operation of offshore wind farms and wind turbines creates job opportunities and helps to mitigate the inequality caused by a lack of development opportunities. However, efforts to balance the three Es have created Campbell's planner's triangle [28] in the OWE policy. There are three major dilemmas for policymakers, as shown in Figure 3.

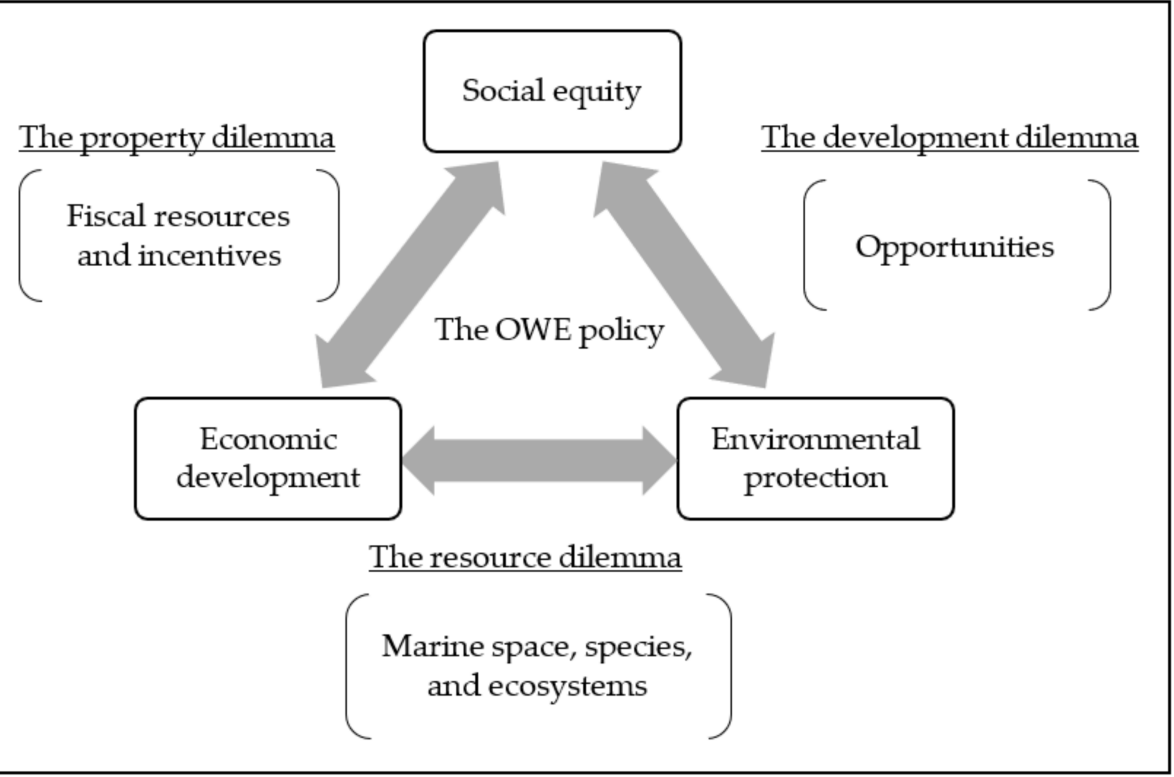

Figure 3. Policy dilemmas of Taiwan's OWE policy.

\subsection{Property Dilemma}

The property dilemma is the divergent interests between economic development and social equity (Figure 3). In Campbell's study [28], the property conflict is focused on ambivalent interests between the private sector's accumulation of private capital and the government's inventions for social equity purposes. The property conflict in Taiwan's OWE policy exists as ambivalent interest in the allocation of the fiscal burden and the redistribution of national finances to other public affairs. When new policies are planned and promoted, they naturally "crowd out" existing public policies, resulting in the redistri- 
bution of national finances to existing policies and causing specific relevant industries to gain or lose private wealth [63].

The development of offshore wind farms is costly, so a governments' fiscal support such as feed-in tariffs and tax incentives are prevailing instruments worldwide [7]. The allocation of the fiscal burden for supporting Taiwan's OWE policy is funded through special budget appropriations. Typically, the government of Taiwan's overall budget for all public sectors is planned, formatted, implemented, and reviewed according to the Budget Act [64]. Article 83 of the Budget Act allows the government to propose a special budget for legislative approval under one of four circumstances: the occurrence of a national defense emergency, a major national economic event, a major calamity, or a major political event [64]. Applying Article 83 of the Budget Act, the Special Act for Forward-Looking Infrastructure (the Special Act) [65] was passed in 2017. The Special Act allows the government to inject special budgets from national debt to establish special national projects [65]. Based on the Special Act, Taiwan's government launched the Forward-looking Infrastructure Development Program (FIDP) to promote and transform Taiwan's national infrastructure in response to emerging state-of-the-art technologies and lifestyle trends [66]. Among the five working items of the green energy pillar in the FIDP, the biggest special budget from 2017 to 2024, excluding the Shalun Smart Green Energy Science City, was allocated to offshore wind energy, as detailed in Table 4. As a percentage of the total budget, the special budget for offshore wind energy was also the highest among the five items at $83.44 \%$ [66]. Notably, the working items in the FIDP are not subject to the current expenditure restrictions set out in Article 23 of the Budget Act.

Table 4. The distribution of the budget for the Green Energy pillar in the FIDP.

\begin{tabular}{ccccc}
\hline Working Items & Total Budget (A) & $\begin{array}{c}\text { General Budget } \\
\text { (incl. Annual Budget, Investments of Private } \\
\text { Sectors and State-Owned Enterprises) }\end{array}$ & $\begin{array}{c}\text { Special Budget } \\
\text { (B) }\end{array}$ & $\begin{array}{c}\text { (B)/(A) } \\
\text { \% }\end{array}$ \\
\hline Smart energy saving & 338.6 & 338.6 & 0.0 \\
Solar energy & 9927.8 & 9924.4 & 3.4 & $0.00 \%$ \\
Offshore wind energy & 93.0 & 15.4 & 77.6 & $83.44 \%$ \\
Terrestrial wind energy & 6755.0 & 6755.0 & 0.0 \\
Shalun Smart Green & 373.2 & 211.0 & 162.2 & $43.36 \%$ \\
Energy Science City ${ }^{1}$ & & & \\
\hline
\end{tabular}

${ }^{1}$ Shalun Smart Green Energy Science City is an industrial park for all types of green energy industries.

A special budget is subject to fewer legal constraints than a general budget. Normally, the government is required to maintain a balanced budget, but a special budget can circumvent this restriction in order to quickly respond to an unanticipated national emergency [64]. The flexibility of the OWE policy's special budget may create a heavier national debt burden and uncertain outcomes in the future. In addition, the government's role in subsidizing a particular public policy often creates more favorable conditions to grow corresponding industries $[67,68]$. While this may contribute to the accumulation of a particular cluster's private wealth $[67,68]$, the government's fiscal support for a particular industry might risk increasing wealth inequality [68]. The government's fiscal mechanisms have boosted Taiwan's offshore wind industry and it is one of the fastest growing industries in the Asia-Pacific region [69]. However, the majority of offshore wind vendors in Taiwan are foreign companies, particularly Danish and German energy vendors [70]. As a result, the development of the offshore wind industry has not provided substantial improvements in Taiwan's domestic market.

Therefore, finding ways to balance the flexibility and auditing of special budgets are necessary to reduce the risks of misusing public funds and to mitigate property dilemmas within the OWE policy and future budget-based policies. Hu et al. [7] conducted a comparison of feed-in tariffs in Germany, Spain, Denmark, and China. Their analysis revealed that establishing benchmarks and examining the appropriate governmental subsidies increases 
the financial solvency of the offshore wind industry. Considering the increasing concerns of using special budgets in Taiwan, regular audits of the special budget appropriations could be the first step toward a robust OWE policy framework. Additionally, reviewing previous special budgets and corresponding projects is helpful for identifying any gaps, "special circumstances," and lessons learned from the past. Furthermore, audit findings could generate benchmarks to assess future applications and produce guidelines to further refine the four "special circumstances" in Article 83 of the Budget Act [64].

\subsection{Resource Dilemma}

The resource dilemma concerns the management of natural resources for purposes of economic development and environmental protection (Figure 3). The pillar of environmental protection extends not only to the physical environment, but also to ecosystem and biodiversity conservation. Economic development is anthropocentric in the sense that a marine ecosystem is regarded as a resource pool for economic development. By contrast, environmental protection advocates tend to define resources as supportive components for sustaining ecosystems from an environment-centric perspective.

The OWE policy is administered by the BOE, an agency of the MOEA. The primary mission of the MOEA is to grow the economy, so OWE policy administrators, offshore wind energy operators, and users are likely to favor an anthropocentric viewpoint with regard to marine resource use. Taiwan's western maritime region has excellent wind conditions; thus, several maritime sites in this region have been designated for wind farms. However, the designated maritime sites for wind farm construction and windmill ship operations overlap greatly with breeding grounds and they are also a major wildlife habitat for the Indo-Pacific humpback dolphin, as shown in Figure 4 [71]. In fact, the Indo-Pacific humpback dolphin is an endangered species [72]. The sightings of this dolphin in 2020 were less than 60 [73].

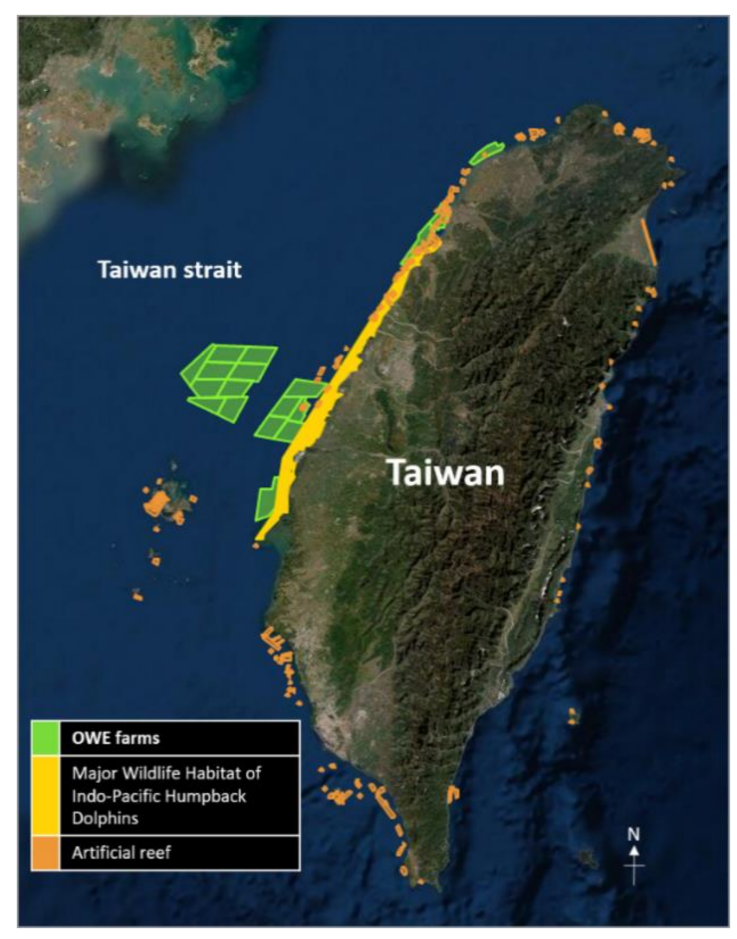

Figure 4. Illustrative map for overlapping marine zones of marine resource use. Source: OCA 2021 [71], this paper arranged the Figure.

Taiwan's OWE policy is designed to directly link environmental protection; however, it is, in fact, not completely harmless to the environment. Taiwan's Environmental Impact Assessment Act states that environmental impact assessments (EIAs) should be conducted prior to commencing development activities that may have an adverse environmental 
impact [74]. EIAs therefore have become the thresholds to assess the conflicts of environmental protection and economic development prior to starting new construction projects. Seeking to reach its 2025 targets for wind turbine deployment, the BOE set a 2017 deadline for completing the EIA process of wind power proposals. This came less than a year after a call for investment was issued. In some cases, EIAs have become a new battleground for competing perspectives that prioritize economic development or environmental protection. The Environmental Protection Administration (EPA), which is responsible for environmental affairs, reviewed 20 OWE EIAs in 2017 [75]. Nevertheless, offshore wind farm construction is associated with a complex series of environmental risks. The main environmental risks included the following: migratory birds colliding with turbine blades, impairment of marine animals' sense of direction due to the noise generated by pile drivers and wind turbines, and interruption of the recovery of marine life in artificial reefs by wind farms and wind turbine installation vessels [76]. Sufficient time for completing EIAs must be provided, and stakeholders must participate in EIAs and express their concerns. On one occasion, the EPA refused to process EIAs within the short timeframe set by the BOE [77].

The designated marine zones for wind farms overlapped with marine breeding zones and habitats of endangered species. This issue has further increased the complexity of the ecological risk assessment and necessitates an ecosystem-based marine spatial plan (MSP). This method delineates the dynamic interactions within ecosystems, giving special attention to the distribution of benefits generated from ecosystem services. Additionally, MSP supports the ecosystem-based approach by factoring in events that only occur in particular marine areas, such as critical spawning areas and areas of stable winds [78]. These considerations limit some activities that are undertaken and the places where the resources can be located. For example, offshore wind pioneers from Denmark, Germany and the Netherlands have applied MSP to determine the marine zones of constraint and the opportunity for offshore wind farms in their sections of the North Sea [79,80]. However, Taiwan's sustained offshore winds are located in a high marine biodiversity zone. Performing an ecosystem-based MSP can help to address conflicts in the use of marine space and ecosystems resulting from the OWE policy. Ideally, the sustainability of the marine resources could be maintained while promoting and implementing the OWE policy [13].

\subsection{Development Dilemma}

The third dilemma, which is developmental in nature, relates to environmental protection and social equity (Figure 3). The debate on environment and social equity stems from past debates on economic growth and social equity. Social equity requires economic development, whereas environmental protection usually necessitates its restriction [28]. Sustainable development calls for social equity to be achieved by creating more economic opportunities for socio-economically disadvantaged individuals without using environmental resources. This is perhaps the biggest paradox in the concept of sustainable development $[81,82]$.

Natural resource-dependent communities are commonly at the bottom level of the labor hierarchy in the economy. They often refuse environmental protection and natural conservation. They view green policy as a luxury of the wealthy [28]. The planned offshore wind farms are located on Taiwan's western coast (Figure 4). The neighboring communities on the western coast are fishing villages, that are often rural and are experiencing an aging and declining population. Commercial fishing and aquaculture have been the main sources of income for generations for these communities. Any policy which may interrupt or prohibit the use of marine resources may encounter resistance.

If economic development enhances social equity and the OWE policy gains acceptance from local residents, the OWE policy certainly might solve social inequity because it creates a new industry for Taiwan. In particular, the third phase of the OWE policy aims to localize the offshore wind energy industry to create domestic job opportunities. However, even before actual job opportunities are created, the construction of the first offshore wind farms 
have already led to the encroachment of marine resources, particularly those related to coastal fisheries and aquaculture [83].

The conflict of property with regard to the ambivalent allocation of national funds and political resources while promoting and implementing the OWE policy complicate the development further. On one hand, Taiwan's government has contributed substantial resources to support the OWE policy with the introduction of financial incentives and designation of more marine zones for offshore wind energy development. On the other hand, the government has tightened its regulation of conventional energy and fishing activities, while also providing financial compensation to fishermen. In order to absorb the fishery sector's financial losses caused by the OWE policy, the Taiwan Fisheries Agency issued the "Fisheries Compensation Standards for Offshore Wind Power Plants" to compensate for fishery-related losses arising from wind farm development, as there is an extensive overlap of existing offshore wind farm sites and fishing grounds [84]. Nevertheless, it remains debatable whether equality can be achieved by providing financial compensation to the groups that are negatively affected by these policies. These actions further exacerbate the unequal distribution of development opportunities among local industries. Those offshore wind energy vendors who receive OWE policy-oriented capital injections become more competitive than vendors in other industries that receive less government support.

"Development needs" consist of multiple dimensions which are reflected in the composition of the OWE policy's stakeholders. Market-oriented groups, such as wind turbine constructors and operators may be concerned with the financial cost and benefits of offshore wind farms, including the cost of EIAs, the location of wind farms, and the potential of wind energy. They may solely focus on the economic aspect of development. Marine resource extractors, including fishers and aquaculture communities may be concerned with the impact of offshore wind turbines on fishing grounds and fishing activities in general. Environmentally oriented interest groups may define air and ocean quality, resource conservation, and open water protection as the foundation for development. Policy makers may tend to focus on achieving the OWE policy goals on schedule. To address the development dilemma resulting from renewable energy policies, "energy democracy" has been introduced in some societies. The early discussion appeared in Germany. Since energy decisions can shape people's lives, the decisions should be articulated jointly by the people and government [85]. Energy democracy refers to the public engagement in energy policymaking procedures and energy transition processes, and collaboration with local communities in governance in order to understand the development needs of various users [86]. The core objectives of energy democracy discussions are to satisfy legitimacy, property, prosperity, and ecological conservation [85]. Therefore, the procedures of energy democracy may alleviate the conflicts of development resulting from different groups of people whose diverse expectations impact OWE policy development. Furthermore, groups that have opposing views on development needs may not necessarily have conflicting positions on other topics. For example, offshore wind farm operators may not necessarily oppose marine conservation, and neither do fishery and aquaculture operators. Additionally, conservationists of specific species may not necessarily oppose offshore wind energy. Therefore, avoiding preconceived notions about particular groups of stakeholders in the energy democracy process may assist in achieving a consensus.

\section{Conclusions}

Sustainable development was first presented as an abstract concept by the UN in the 1980s. It has evolved into a goal that national and local governments can implement through public policies and across public domains in the $21^{\text {st }}$ century. In recent years, Taiwan has selected the energy sector as one of its policy priorities toward a sustainable future. Offshore wind energy has been recognized as the focus for renewable energy development, aimed at promoting an energy transition. This paper applied Dunn's policy analysis approach to provide policy-relevant knowledge of the OWE policy, which was articulated by a package of laws and policies in the context of energy transition. The 
OWE policy was conceived with good intentions, but it neglect other facets related to sustainable development. This shortfall has led to unanticipated dilemmas resulting from the imbalance of economic growth, social equity, and environmental protection.

This paper further analyzed the unanticipated dilemmas through a sustainable development perspective. These identified dilemmas are: questionable distribution of public property and accumulation of private property, conflicts of marine resource use, and challenges of development opportunities. In order to address these policy dilemmas, this paper recommended a review of Taiwan's special budgetary mechanisms and regular audits of special budgets to increase transparency and accountability of public property, performing an ecosystem-based MSP to mitigate conflicts in resources, and introduce energy democracy to alleviate the development dilemma.

Taiwan's OWE policy is a strategy toward energy transition. To reach its goals, it must meet the wide-ranging objectives of economic development, environmental protection, and social equity. The development of the idea of sustainable development in the last few decades has gradually shaped a category of sustainable development policy in the public policy doctrine [87]. Each category involves unique logic, objectives, social problems, stakeholders, interest groups and so on. Classifying public affairs into different policy categories could result in different performances. Considering OWE policy as not only an energy policy but also a sustainable development policy, could facilitate the smooth promotion and implementation of the OWE policy. With increasing global trends shifting away from fossil fuel energy to clean and renewable energy, the findings of this paper on Taiwan's practices may contribute to current offshore wind pioneers' experiences, and possibly benefit future renewable energy policies. Further study on articulating policy principles of sustainable development in the energy sector could be undertaken in order to improve the design of future clean, renewable energy, or new energy related policies.

Funding: This research was funded by the Taiwan Ministry of Science and Technology, MOST 109-2410-H-019-029-MY2.

Institutional Review Board Statement: Not applicable.

Informed Consent Statement: Not applicable.

Data Availability Statement: Not applicable.

Acknowledgments: The author thanks the comments on the draft from Lin, Yen-Bor and Lin, Li-Ching.

Conflicts of Interest: The author declares no conflict of interest.

\section{References}

1. United Nations. Sustainable Development Goals. 2015. Available online: https://www.un.org/sustainabledevelopment/ (accessed on 12 November 2020).

2. United Nations. Sustainable Development Goals-Goal 7. 2015. Available online: https://sdgs.un.org/goals/goal7 (accessed on 12 November 2020).

3. Toke, D. The UK offshore wind power programme: A sea-change in UK energy policy? Energy Policy 2011, 39, 526-534. [CrossRef]

4. Dawley, S. Creating New Paths? Offshore Wind, Policy Activism, and Peripheral Region Development. Econ. Geogr. 2014, 90, 91-112. [CrossRef]

5. Söderholm, P.; Pettersson, M. Offshore wind power policy and planning in Sweden. Energy Policy 2011, 39, 518-525. [CrossRef]

6. Luo, L.; Lacal-Arantegui, R.; Wieczorek, A.J.; Negro, S.O.; Harmsen, R.; Heimeriks, G.J.; Hekkert, M.P. A systemic assessment of the European offshore wind Innovation: Insights from the Netherlands, Denmark, Germany and the United Kingdom. JRC Sci. Policy Rep. 2012, 73066, 1-86.

7. Hu, Z.; Wang, J.; Byrne, J.; Kurdgelashvili, L. Review of wind power tariff policies in China. Energy Policy 2013, 53, 41-50. [CrossRef]

8. Wang, L.; Wang, K.-H. Dynamic Stability Analysis of a DFIG-Based Offshore Wind Farm Connected to a Power Grid Through an HVDC Link. IEEE Trans. Power Syst. 2010, 26, 1501-1510. [CrossRef]

9. Hsieh, M.-F.; Lin, C.-K.; Lin, I.-H. Design and Analysis of High Temperature Superconducting Generator for Offshore Wind Turbines. IEEE Trans. Magn. 2013, 49, 1881-1884. [CrossRef]

10. Huang, Y.-H.; Wu, J.-H. A transition toward a market expansion phase: Policies for promoting wind power in Taiwan. Energy 2009, 34, 437-447. [CrossRef] 
11. Liou, H.M. Wind power in Taiwan: Policy and development challenges. Energy Policy 2011, 39, 3238-3251. [CrossRef]

12. Kao, S.-M.; Pearre, N.S. Administrative arrangement for offshore wind power developments in Taiwan: Challenges and prospects. Energy Policy 2017, 109, 463-472. [CrossRef]

13. Zhang, Y.; Zhang, C.; Chang, Y.-C.; Liu, W.-H.; Zhang, Y. Offshore wind farm in marine spatial planning and the stakeholders engagement: Opportunities and challenges for Taiwan. Ocean. Coast. Manag. 2017, 149, 69-80. [CrossRef]

14. Chiu, M.-S. Tensions in implementing the "energy-conservation/carbon-reduction" policy in Taiwanese culture. Energy Policy 2013, 55, 415-425. [CrossRef]

15. Taiwan Institute for Sustainable Energy (TAISE). 2020 Public Opinion on Electricity Use and Energy Transition in Taiwan. 2020. Available online: https://taise.org.tw/news-view.php?ID=1770 (accessed on 14 April 2021). (In Chinese).

16. Opview Inside. Opview. 2021. Available online: https://www.opview.com.tw/ (accessed on 1 April 2021).

17. Tech News. A Clear National Project, a Real Quiet Revolution, and an Offshore Wind Turbine. 2020. Available online: https: / technews.tw/2020/05/03/changhua-offshore-wind-power-industry-project/ (accessed on 11 November 2020). (In Chinese).

18. Taiwan Environmental Information Association. Offshore Wind Turbines Destroy Fishing Grounds: Yunlin County's Fishers Call for Stopping Construction of Offshore Wind Turbines. 2020. Available online: https:/ / e-info.org.tw/node/226272 (accessed on 11 November 2020). (In Chinese).

19. Dunn, W.N. Probing the Boundaries of Ignorance in Policy Analysis. Am. Behav. Sci. 1997, 40, 277-298. [CrossRef]

20. Patton, C.V.; Sawicki, D.S.; Clark, J.J. Basic Methods of Policy Analysis and Planning, 3rd ed.; Routledge: London, UK; New York, NY, USA, 2016; pp. 1-464.

21. Dunn, W.N. Public Policy Analysis, 6th ed.; Routledge: London, UK; New York, NY, USA, 2018; pp. 1-468.

22. United Nations. Report of the World Commission on Environment and Development. 1987. Available online: https:// digitallibrary.un.org/record/139811/files/A_42_427-EN.pdf (accessed on 23 November 2020).

23. United Nations. Report of the United Nations Conference on Environment and Development. 1992. Available online: https://www.un.org/en/development/desa/population/migration/generalassembly/docs/globalcompact/A_CONF.151_ 26_Vol.I_Declaration.pdf (accessed on 3 November 2020).

24. United Nations. United Nations Millennium Declaration. 2000. Available online: https://www.un.org/en/development/ devagenda/millennium.shtml (accessed on 3 November 2020).

25. United Nations. Report of the World Summit on Sustainable Development. 2002. Available online: https://digitallibrary.un.org/ record/478154/files/A_CONF-199_20-EN.pdf (accessed on 3 November 2020).

26. Berke, P.R. Does Sustainable Development Offer a New Direction for Planning? Challenges for the Twenty-First Century. J. Plan. Lit. 2002, 17, 21-36. [CrossRef]

27. Tomislav, K. The concept of sustainable development: From its beginning to the contemporary issues. Zagreb Int. Rev. Econ. Bus. 2018, 21, 67-94.

28. Campbell, S. Green Cities, Growing Cities, Just Cities?: Urban Planning and the Contradictions of Sustainable Development. J. Am. Plan. Assoc. 1996, 62, 296-312. [CrossRef]

29. Campbell, S.D. The planner's triangle revisited: Sustainability and the evolution of a planning ideal that can't stand still. J. Am. Plan. Assoc. 2016, 82, 388-397. [CrossRef]

30. Masson-Delmotte, V.; Zhai, P.; Pörtner, H.O.; Roberts, D.; Skea, J.; Shukla, P.R.; Pirani, A.; Moufouma-Okia, W.; Péan, C.; Pidcock, R.; et al. (Eds.) Global Warming of $1.5^{\circ} \mathrm{C}$; Intergovernmental Panel on Climate Change (IPCC): Geneva, Switzerland, 2019; Available online: https://www.ipcc.ch/site/assets/uploads/sites/2/2019/06/SR15_Full_Report_High_Res.pdf (accessed on 12 November 2020).

31. United Nations. United Nations Framework Convention on Climate Change. 1992. Available online: https://unfccc.int/files/ essential_background/background_publications_htmlpdf/application/pdf/conveng.pdf (accessed on 12 November 2020).

32. Taipower. Historical Power Supply and Demand Information. 2021. Available online: https://www.taipower.com.tw/ (accessed on 10 March 2021). (In Chinese).

33. Lin, J.J. Characterization of the major chemical species in PM2.5 in the Kaohsiung City, Taiwan. Atmos. Environ. 2002, 36, 1911-1920. [CrossRef]

34. Guo, Y.L.; Lin, Y.-C.; Sung, F.C.; Huang, S.L.; Ko, Y.C.; Lai, J.S.; Su, H.-J.; Shaw, C.K.; Lin, R.S.; Dockery, D. Climate, traffic-related air pollutants, and asthma prevalence in middle-school children in Taiwan. Environ. Health Perspect. 1999, 107, 1001-1006. [CrossRef]

35. Taiwan Ministry of Transportation and Communications. Projection of Future Sea Level Changes around Taiwan. 2016. Available online: https:/ / www.ihmt.gov.tw / periodical/pdf/B1058130.pdf (accessed on 29 November 2020). (In Chinese)

36. Chuang, K.-J.; Yan, Y.-H.; Chiu, S.-Y.; Cheng, T.-J. Long-term air pollution exposure and risk factors for cardiovascular diseases among the elderly in Taiwan. Occup. Environ. Med. 2011, 68, 64-68. [CrossRef]

37. Taipei Times. Climate Groups Call for Cleaner Kaohsiung Air. 2021. Available online: https://www.taipeitimes.com/News/ taiwan/archives/2021/04/05/2003755115 (accessed on 12 April 2021).

38. Taipei Times. Environmental Groups Demand EPA Head Resign. 2020. Available online: https://www.taipeitimes.com/News/ taiwan/archives/2020/11/18/2003747131 (accessed on 12 April 2021).

39. Mulligan, S. Energy and human ecology: A critical security approach. Environ. Politics 2011, 20, 633-649. [CrossRef] 
40. Rasiah, R.; Shahrivar, R.B.; Yap, X.-S. Institutional support, innovation capabilities and exports: Evidence from the semiconductor industry in Taiwan. Technol. Forecast. Soc. Chang. 2016, 109, 69-75. [CrossRef]

41. Taiwan Ministry of Economic Affairs (MOEA). Framework of Taiwan's Sustainable Energy Policy.2008. Available online: https:/ / grb-topics.stpi.narl.org.tw / file/download?flsId=4b1141c264eef5760164eef862b70013 (accessed on 2 November 2020). (In Chinese).

42. Taiwan Ministry of Economic Affairs (MOEA). Renewable Energy Development Act. 2009. Available online: https://law.moj.gov. tw /ENG/LawClass /LawAll.aspx?pcode=J0130032 (accessed on 2 November 2020).

43. Taiwan National Council for Sustainable Development (NCSD). 2019 Year Review of Taiwan Sustainable Development Goals. 2020. Available online: https:/ / nsdn.epa.gov.tw / (accessed on 2 November 2020).

44. Ho, M.-S. The Fukushima effect: Explaining the resurgence of the anti-nuclear movement in Taiwan. Environ. Politics 2014, 23, 965-983. [CrossRef]

45. Ho, J.-C.; Kao, S.-F.; Wang, J.-D.; Su, C.-T.; Lee, C.-T.P.; Chen, R.-Y.; Chang, H.-L.; Ieong, M.C.F.; Chang, P.W. Risk perception, trust, and factors related to a planned new nuclear power plant in Taiwan after the 2011 Fukushima disaster. J. Radiol. Prot. 2013, 33, 773-789. [CrossRef] [PubMed]

46. Taiwan Executive Yuan. Nuclear-Free Homeland Policy Remains Unchanged. 2016. Available online: https:/ / english.ey.gov.tw / Page/61BF20C3E89B856/e61c7f0b-9918-4c62-b80b-8a255f1f4aa8 (accessed on 12 November 2020).

47. Taiwan Ministry of Economic Affairs (MOEA). Promote Green Energy, Increase Nature Gas, Reduce Coal-Fired, Achieve Nuclear-Free. 2021. Available online: https:/ / www.moea.gov.tw/ (accessed on 26 March 2021).

48. Taiwan's Atomic Energy Council (AEC). The Schedule of Decommissioning Nuclear Power Plants. 2020. Available online: https: / / www.aec.gov.tw/ (accessed on 1 November 2020). (In Chinese)

49. Taipower. Wind Power. Available online: https: / www.taipower.com.tw $/$ tc $/$ page.aspx? $\mathrm{mid}=204 \& \mathrm{cid}=1581 \& \mathrm{cchk}=82 \mathrm{fb} 957 \mathrm{e}-$ 2fe8-49b6-90a9-b750387de936 (accessed on 2 April 2021). (In Chinese).

50. Epochtimes. Wind Farm Benefits to Tourism? Local Residents Worry about Destroying the Village. 2021. Available online: https:/ / www.epochtimes.com/b5/21/5/9/n12934837.htm (accessed on 10 May 2021). (In Chinese).

51. Chen, F.; Chang, S.Y.; Hsiao, T.C.; Lu, Y.R.; Yang, T.Y. Assessment of renewable energy reserves in Taiwan. Renew. Sustain. Energy Rev. 2010, 14, 2511-2528. [CrossRef]

52. Chuang, M.-T.; Chang, S.-Y.; Hsiao, T.-C.; Lu, Y.-R.; Yang, T.-Y. Analyzing major renewable energy sources and power stability in Taiwan by 2030. Energy Policy 2019, 125, 293-306. [CrossRef]

53. Liu, W.-T.; Wu, Y.-K.; Lee, C.-Y.; Chen, C.-R. Effect of Low-Voltage-Ride-Through Technologies on the First Taiwan Offshore Wind Farm Planning. IEEE Trans. Sustain. Energy 2010, 2, 78-86. [CrossRef]

54. Taiwan Executive Yuan. Forward-looking Infrastructure Development Program. 2017. Available online: https://www.ey.gov.tw / File/D2263421E99C6C1C (accessed on 13 November 2020). (In Chinese)

55. Taiwan Ministry of Economic Affairs (MOEA). The Four-Year Wind Power Promotion Plan. 2017. Available online: https: //www.moeaboe.gov.tw/ECW/populace/content/wHandMenuFile.ashx?file_id=4107 (accessed on 22 November 2020).

56. Taiwan Ministry of Economic Affairs (MOEA). The Development of Taiwan's Offshore Wind Power. 2019. Available online: https:/ / www.moea.gov.tw /MNS/ietc_e/bulletin/Bulletin_En.aspx?kind=38\&html=1\&menu_id=25449\&bull_id=6320 (accessed on 11 November 2020).

57. Taiwan Bureau of Energy of the Ministry of Economic Affairs (BOE). Draft of Application for Development and Site Planning of Offshore Wind Power Zones. 2020. Available online: https:/ /www.moeaboe.gov.tw/ECW/populace/news/Board.aspx?kind= 3\&menu_id=57\&news_id=17656 (accessed on 21 November 2020). (In Chinese)

58. Taiwan Executive Yuan. The Report to the 3rd Session of the 10th Legislature. 2021. Available online: https:/ /www.ey.gov.tw/ File/50910A66F623167A/b2af4523-3ee3-4e9f-97dd-ad2feeb33da2?A=C (accessed on 12 May 2021).

59. Formosa Offshore Wind Farm (FOW1). About Formosa I. 2021. Available online: https:// formosa1windpower.com/en/ (accessed on 10 March 2020).

60. Taipei Times. Fishers from Yunlin County Criticize Wind Turbine Project. 2020. Available online: https://www.taipeitimes.com/ News/taiwan/archives/2020/08/14/2003741665 (accessed on 12 April 2021).

61. Liberty Times Net. Controversies in Yunlin Offshore Wind Farm Has Not yet Settled. 2021. Available online: https:/ / ec.ltn.com. tw/article/breakingnews/3464979 (accessed on 10 May 2021). (In Chinese).

62. Liberty Times Net. Unsolved Controversy of Heilong Wind Farm 2021. Available online: https://news.ltn.com.tw/news/life/ breakingnews / 3433750 (accessed on 13 May 2020). (In Chinese).

63. Godschalk, D.R. Land Use Planning Challenges: Coping with Conflicts in Visions of Sustainable Development and Livable Communities. J. Am. Plan. Assoc. 2004, 70, 5-13. [CrossRef]

64. Taiwan Directorate-General of Budget, Accounting and Statistics (DGBAS). Budget Act. 2016. Available online: https://law.moj. gov.tw/ENG/LawClass/LawAll.aspx?pcode=T0020001 (accessed on 15 November 2020).

65. Taiwan National Development Council. Special Act for Forward-Looking Infrastructure. 2017. Available online: https://law.moj. gov.tw/ENG/LawClass/LawAll.aspx?pcode=A0030293 (accessed on 6 March 2021).

66. Taiwan Office of Energy and Carbon Reduction of Executive Yuan (OECR). Forward-Looking Infrastructure Development Program: Green Energy. 2017. Available online: https:/ / www.ey.gov.tw / File/694A3325D84DAB64 (accessed on 13 November 2020). (In Chinese) 
67. Dioikitopoulos, E.V.; Turnovsky, S.J.; Wendner, R. Public policy, dynamic status preferences, and wealth inequality. J. Public Econ. Theory 2019, 21, 923-944. [CrossRef]

68. Hockett, R.C.; Omarova, S.T. Private wealth and public goods: A case for a national investment authority. J. Corp. Law 2017, 43, 437-491. [CrossRef]

69. Buljan, A. Taiwan to Become Second Largest APAC Offshore Wind Market. 2020. Available online: https://www.offshorewind.biz/20 20/08/28/taiwan-to-become-second-largest-apac-offshore-wind-market/ (accessed on 5 September 2021).

70. Common Wealth Magazine. A Big Win for Foreign Company. 2018. Available online: https://www.cw.com.tw/article/5089627 (accessed on 2 May 2021). (In Chinese)

71. Taiwan Ocean Conservation Administration (OCA). iOcean. 2021. Available online: https://iocean.oca.gov.tw/OCA_ OceanConservation/GIS/MyGIS.aspx (accessed on 2 May 2021).

72. International Union for Conservation of Nature (IUCN). Indo-Pacific Humpback Dolphin, IUCN Red List. 2021. Available online: https:/ / www.iucnredlist.org/species/82031425/123794774 (accessed on 28 March 2021).

73. Lin, M.; Caruso, F.; Liu, M.; Lek, S.; Li, K.; Gozlan, R.E.; Li, S. Food risk trade-off in the Indo-Pacific humpback dolphin: An exploratory case study. Aquat. Conserv. 2020, 30, 860-867. [CrossRef]

74. Taiwan Environmental Protection Administration (EPA). Environmental Impact Assessment Act. 2003. Available online: https: / / law.moj.gov.tw /ENG/LawClass/LawAll.aspx?pcode=O0090001 (accessed on 22 November 2020).

75. Taiwan Environmental Protection Administration (EPA). Environmental Impact Assessment Inquiry System. Available online: https: / / eiadoc.epa.gov.tw /EIAWEB/Default.aspx\#DefaultContent2 (accessed on 22 March 2021).

76. Chiau, W.Y. The development of offshore wind farms in Taiwan: A marine policy perspective. J. Nat. Dev. Stud. 2019, 18, 55-124. (In Chinese)

77. The Storm Media. Ex-Deputy Minister of Environmental Protection Agency, Thomas Chan's Anger at the Risk of Developing Offshore Wind Power. 2017. Available online: https:/ / www.storm.mg/article/332550?page=1 (accessed on 2 March 2021). (In Chinese).

78. Douvere, F. The importance of marine spatial planning in advancing ecosystem-based sea use management. Mar. Policy 2008, 32, 762-771. [CrossRef]

79. Azzellino, A.; Ferrante, V.; Kofoed, J.P.; Lanfredi, C.; Vicinanza, D. Optimal siting of offshore wind-power combined with wave energy through a marine spatial planning approach. Int. J. Mar. Energy 2013, 3, e11-e25. [CrossRef]

80. Jay, S. Planners to the rescue: Spatial planning facilitating the development of offshore wind energy. Mar. Pollut. Bull. 2010, 60, 493-499. [CrossRef]

81. Brunnschweiler, C.N. Cursing the Blessings? Natural Resource Abundance, Institutions, and Economic Growth. World Dev. 2008, 36, 399-419. [CrossRef]

82. Stern, D.I.; Common, M.S.; Barbier, E.B. Economic growth and environmental degradation: The environmental Kuznets curve and sustainable development. World Dev. 1996, 24, 1151-1160. [CrossRef]

83. Chinatimes. The Hometown Has Been Completed Change. 2021. Available online: https://www.chinatimes.com/opinion/2021 0531003074-262104?chdtv (accessed on 31 May 2021). (In Chinese).

84. Fishery Agency, the Republic of China (Taiwan). Fisheries Compensation Standards for Offshore Wind Power Plants. 2016. Available online: https:/ / www.fa.gov.tw/cht/LawsRuleFisheries/content.aspx?id=540\&chk=5207eda4-0453-4482-a789-08406 f114339\&param (accessed on 10 March 2020). (In Chinese)

85. Szulecki, K. Conceptualizing energy democracy. Environ. Politics 2018, 27, 21-41. [CrossRef]

86. Van Veelen, B. Negotiating energy democracy in practice: Governance processes in community energy projects. Environ. Politics 2018, 27, 644-665. [CrossRef]

87. Lemons, J.; Brown, D.A. (Eds.) Sustainable Development: Science, Ethics, and Public Policy; Springer: Dordrecht, The Netherlands, 1995; pp. 1-283. 